\title{
PENERAPAN METODE QUANTUM TEACHING UNTUK MENINGKATKAN HASIL BELAJAR FISIKA PADA MATERI OPTIK
}

\author{
Fatkhur Rohman', Siti Kotimah'2 dan Ayu Lusiyana ${ }^{3}$ \\ ${ }^{1,3}$ Sekolah Tinggi Keguruan dan IImu Pendidikan (STKIP) Nurul Huda \\ ${ }^{2}$ Madrasah Tsanawiyah Nurul Huda \\ 1,2,3 Jl Kota Baru Desa Sukaraja Kec. Buay Madang Kab. OKU Timur \\ ${ }^{* 1}$ Atkhur@gmail.com \\ 3 Ayu.lusiyana@live.com
}

\begin{abstract}
Abstrak
Telah dilakukan penelitian tindakan kelas dengan menerapkan metode pembelajaran quantum teaching untuk meningkatkan hasil belajar fisika pada materi optik di MTs Nurul Huda.Penelitian ini dilatar belakangi dari tidak maksimalnya siswa dalam memahami materi pelajaran yang disampaikan oleh guru mata pelajaran IPA karena siswa sering kali hanya bermain dan bergurau, tidak begitu mendengarkan penjelasan guru. Penulis menemukan dari literatur bahwa metode pengajaran yang tepat dengan masalah tersebut adalah metode quantum teaching. Berdasarkan hasil penelitian disimpulkan bahwa pembelajaran quantum teaching dapat meningkatkan hasil belajar kognitif, afektif, dan psikomotorik siswa pada materi optik di kelas VIII ${ }_{1}$ MTs Nurul Huda. Peningkatan nilai rata-rata kognitif pada siklus I dari 70,43 menjadi 80,43 . Ketuntasan klasikal mengalami peningkatan dari $61 \%$ menjadi $87 \%$. Nilai rata-rata afektif siswa dalam hal minat meningkat dari siklus I sebesar $68 \%$ menjadi $85 \%$ pada siklus II.Nilai rata-rata psikomotoriksiklus I sebesar $70 \%$ meningkat pada siklus II menjadi $84 \%$.
\end{abstract}

Kata kunci: Metode Quantum Teaching, Hasil Belajar Siswa, Optik.

\section{PENDAHULUAN}

Madrasah Tsanawiyah (MTs) Nurul Huda merupakan sekolah di jenjang pendidikan menengah yang memiliki visi agar unggul dalam mutu, iman, takwa dan perilaku. Misi untuk menjalankan visi tersebut yakni tercipta suasana religius di lingkungan sekolah, mengembangkan kecintaan terhadap budaya bangsa, menumbuhkembangkan kebiasaan perilaku yang terpuji, melaksanakan proses belajar mengajar yang efektif dan efisien, serta mengembangkan penguasaan teknologi. Untuk mewujudkan hal tersebut guru perlu mengoptimalkan pengajaran dan pendidikan yang dilakukan di kelas masing-masing.

Memiliki ratusan siswa yang berada dalam usiawajib belajar, para siswa di MTs Nurul Huda seperti siswa tingkatan SLTP atau sederajatlainnya sedang mengalami tahapan kehidupan pada fase remaja. Para remaja biasanya berupaya menemukan jati diri yang tercermin dalam tindakan sangat aktif, ingin mencari tahu, ingin mencoba hal baru, memiliki kemampuan berpikir yang lebih maju daripada anak-anak dan sangat mempedomani perkataan tesman sebayanya. Kondisi ini tidak boleh terlepas dari kontrol orang tua di rumah, guru di sekolah serta masyarakat di lingkungan sekitar.

Kenyataannya siswa remaja kebanyakan aktif dan berkembang tanpa mendapatkan bimbingan, arahan dan kontrol yang ketat dari orangtua dan guru.Di kelas siswa sering kali hanya bermain dan bergurau bersama temantemannya, tidak begitu mendengarkan penjelasan dari guru di depan kelas.Mereka sibuk mengeksplorasi hal-hal di luar pelajaran, seperti isu-isu yang hangat di media sosial, game-game terbaru yang selalu mereka mainkan, atau ketertarikan terhadap lawan jenis.Akibatnya tentu saja siswa tidak maksimal dalam memahami materi pelajaran yang diajarkan gurunya, terbukti dengan rendahnya nilai hasil belajar mereka (nilai ulangan harian dan ujian semester). Perilaku siswa remaja yang berkembang ke arah negatif ini juga berdampak terhadap tidak tercapainya visi dan misi sekolah secara optimal. Bagaimana bisa 
sekolah menjadi unggul dalam mutu, iman, takwa dan perilaku jika siswanya saja tidak bisa memprioritaskan kepentingannya dengan tepat, bukan menuntut ilmu yang menjadi tujuan mereka berangkat ke sekolah.

Dalam upaya meningkatkan kualitas pembelajaran di kelas, guru dituntut untuk bisa mengupayakan berbagai macam cara untuk mengatasi ketidakseriusan siswa dalam belajar. Guru hendaknya bisa memanfaatkan pola perilaku siswa remaja tersebut dan mengarahkannya ke arah yang lebih baik sehingga siswa bisa belajar dengan sungguhsungguh. Penulis meyakini bahwa setiap siswa memiliki modal yang besar untuk bisa belajar dengan baik dan memahami materi pelajaran yang diajarkan. Tidak ada yang namanya siswa pintar dan siswa yang kurang pintar, yang ada hanyalah siswa yang sudah memahami dan menyadari tujuannya datang ke sekolah, dan siswa yang belum bisa memahami dan menyadari tujuannya datang ke sekolah.

Memanfaatkan pola perilaku siswa remaja bisa dilakukan dengan mengakali situasi pembelajaran di kelas. Maksud mengakali adalah dengan mengatur atau mendesain lingkungan dan suasana belajar menjadi menyenangkan bahkan terkesan bermain-main namun sebenarnya serius. Setelah mengkaji dari beberapa literatur, penulis menemukan bahwa metode pengajaran yang tepat dengan hal tersebut adalah metode quantum teaching. Metode quantum teachingmerupakan suatu model dengan penggunaan bahan ajar yang meriah serta berfokus pada hubungan dinamis di dalam lingkungan kelas. Dengan menggunakan metode yang bisa menyearahkan gejolak perilaku siswa remaja yang mana siswa belajar dengan suasana riang gembira dan menyenangkan, diharapkan siswa bisa cepat menyerap hal-hal yang diajarkan oleh guru baik itu materi pelajaran maupun nilai-nilai kehidupan untuk meningkatkan kualitas diri para siswa. Serta diharapkan pembelajaran yang berlangsung di kelas menjadi lebih optimal yang terlihat dari penilaian hasil belajar para siswa.

Dengan dilandasi oleh permasalahan diatas, maka penulis sebagai guru mata pelajaran IPA Terpadu tertarik mengadakan penelitian dengan mengkaji secara ilmiah mengenai "Penerapan Metode Quantum Teaching untuk Meningkatkan Hasil Belajar Siswa pada Materi Optik di Kelas VIII ${ }_{1}$ MTs Nurul Huda Sukaraja".

Berdasarkan uraian latar belakang diatas, maka penulis merumuskan masalah dalam penelitian ini sebagai berikut: "Apakah penerapan metode quantum teaching dapat meningkatkan hasil belajar fisika pada materi optik di kelas VIII1 MTs Nurul Huda Sukaraja Tahun Pembelajaran 2015/2016"?

Sejalan dengan rumusan masalah yang dikemukakan di atas, maka tujuan penelitian tindakan (action research) ini adalah untu mengetahui meningkat tidaknya hasil belajar mata pelajaran fisika materi optik siswa di kelas VIII1 MTs Nurul Huda Sukaraja Tahun Pembelajaran 2015/2016 dengan penerapan metode quantum teaching.

\section{METODE PENELITIAN}

\section{Metode Penelitian}

Metode penelitian menurut Fuchan (1982: 23) adalah strategi umum yang dianut dalam pengumpulan data yang diperlukan, guna menjawab persoalan yang dihadapi. Dalam penelitian ini, peneliti menggunakan penelitian tindakan kelas. Penelitian adalah suatu proses pemecahan masalah yang dilakukan secara sistematis, empiris dan terkontrol. Tindakan dapat diartikan sebagai perlakuan tertentu yang dilakukan oleh peneliti, yakni guru. Sedangkan kelas menunjukkan pada tempat proses pembelajaran berlangsung. Dari penjelasan diatas dapat diartikan sebagai proses pengkajian masalah pembelajaran di dalam kelas melalui refleksi diri dalam upaya untuk memecahkan masalah tersebut dengan cara melakukan berbagai tindakan yang terencana dalamsituasi nyata serta menganalisis setiap pengaruh dari perlakuan tersebut.

\section{Tempat Penelitian}

Penelitian tindakan kelas ini dilaksanakan dikelas VIII ${ }_{1}$ MTs Nurul Huda Sukaraja Tahun Pembelajaran 2015/2016. 


\section{Waktu Penelitian}

Penelitian ini dilaksanakan pada pertengahan semester genap, karena PTK memerlukan minimal dua siklus yang dilakukan dalam proses belajar mengajar pada jam efektif di kelas

\section{Siklus PTK}

PTK ini dilaksanakan melalui dua siklus, setiap siklus dilaksanakan mengikuti prosedur perencanaan (planning), tindakan (action), pengamatan (observation), dan refleksi (reflection).Melalui kedua siklus tersebut dapat diamati peningkatan hasil belajar siswa pada pelajaran fisika materi pembelajaran optik.

\section{Subjek Penelitian}

Sebagai subjek dalam penelitian ini adalah siswa kelas VIII ${ }_{1}$ MTs Nurul Huda Sukaraja Tahun Pembelajaran 2015/2016 dengan jumlah siswa sebanyak 23 siswa. Pemilihan tempat ini bertujuan untuk meningkatkan hasil belajar siswa yang mana kelas VIII1 merupakan kelas dengan nilai fisika paling rendah dari kelas VIII yang ada di MTs Nurul Huda berdasarkan hasil ulangan fisika pada materi sebelumnya.

\section{Rencana Tindakan}

Dalam pelaksanaannya PTK ini menggunakan penelitian tindakan model Kemmis and McTaggart (1988). Menurut Hopkins (1993), pelaksanaan penelitian tindakan dilakukan membentuk spiral yang dimulai dari merasakan adanya masalah atau refleksi awal, menyusun perencanaan, melaksanakan tindakan, melakukan observasi, mengadakan refleksi, melakukan rencana ulang, melaksanakan tindakan dan seterusnya

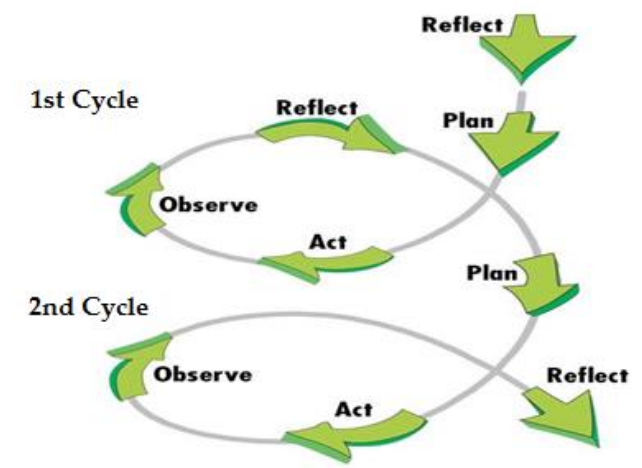

Gambar 1. PTK Model Kemmis and McTaggart (1988)
Penjelasan dari alur diatas adalah sebagai berikut:

\section{Siklus I:}

Refleksi awal

Proses refleksi awal dalam penelitian ini Yakni menganalisis pembelajaran yang berlangsung. Kemudian dari sini peneliti merasakan adanya masalah mendesak yang harus dicari jalan keluarnya. Identifikasi masalah tidak hanya dilakukan dengan berfikir saja, akan tetapi dilakukan dengan menganalisis kejadian yang didasarkan pada data secara empiris.

Perencanaan

Perencanaan peneltian mencakup beberapa tahapan yaitu:

a. Merencanakan pembelajaran yang akan diterapkan

b. Menyiapkan sumber, bahan dan alat yang diperlukan

c. Menentukan skenario pembelajaran

d. Mengembangkan format evaluasi

e. Mengembangkan format observasi

Aksi

Pada tahap ini peneliti menerapkan tindakan yang mengacu pada skenario pembelajaran

Observasi

Tahap observasi peneliti melakukan tahapan meliputi:

a. Melakukan observasi sesuai dengan format observasi yang telah ditentukan

b. Menilai hasil tindakan dengan menggunakan format lembar kinerja siswa

Refleksi

Refleksi dalam penelitian ini peneliti melakukan beberap tahap yaitu:

a. Melakukan evaluasi tindakan yang telah dilakukan

b. Melakukan pertemuan untuk membahas hasil evaluasi tentang skenario pembelajaran dan format lembar kerja siswa

c. Memperbaiki pelaksanaan tindakan sesuai dengan hasil evaluasi untuk digunakan pada siklus berikutnya.

\section{Siklus II:}

Perencanaan Ulang

a. Identifikasi masalah yang muncul pada siklus I dan belum teratasi dan penetapan alternatif pemecahan masalah

b. Menentukan indikator pencapaian hasil belajar

c. Pengembangan program tindakan II

Aksi

Pelaksanaan program tindakan II yang mengacu pada identifikasi masalah yang muncul pada silkus I sesuai dengan alternatif pemecahan masalah yang sudah ditentukan. 


\section{Observasi}

a. Melakukan observasi sesuai dengan format observasi yang telah sudah disiapkan dan mencatat semua hal-hal yang diperlukan yang terjadi selama pelaksanaan tindakan berlangsung.

b. Menilai hasil tindakan dengan menggunakan format yang sudah ditentukan

Refleksi

a. Melakukan evaluasi tindakan siklus II berdasarkan data yang terkumpul

b. Membahas hasil evaluasi terhadap skenario pembelajaran pada siklus II

c. Membuat kesimpulan atas pelaksanaan pembelajaran fisika materi optik.

\section{Data Penelitian}

Data Kualitatif

Termasuk data kualitatif adalah:

a. Gambaran umum MTs Nurul Huda Sukaraja.

b. Pelaksanaan pembelajaran fisika siswa kelas VIII ${ }_{1}$ MTs Nurul Huda Sukaraja.

c. Literatur-literatur mengenai konsep pembelajaran, pengajaran, metode quantum teaching.

Data kuantitatif

Termasuk data kuantitatif adalah:

a. Administrasi pembelajaran fisika di kelas VIII ${ }_{1}$ MTs Nurul Huda Sukaraja

b. Proses pelaksanaan pembelajaran fisika di kelas VIII 1 MTs Nurul Huda Sukaraja.

c. Hasil belajar siswa di kelas VIII 1 MTs Nurul Huda Sukaraja.

\section{Teknik pengumpulan data}

Teknik pengumpulan data yakni membicarakan tentang bagaimana cara penulis mengumpulkan data. Dalam penelitian ini penulis menggunakan beberapa metode dalam mengumpulkan data, sebagai berikut:

a. Metode Observasi (pengamatan)

Bungin (2001: 24) menyatakan bahwa metode observasi atau pengamatan adalah kegiatan keseharian manusia dengan menggunakan panca indera mata dan dibantu dengan panca indera lainnya.Melalui observasi, penulis belajar tentang perilaku, dan makna dari perilaku tersebut (Sugiyono, 2007:34).

Observasi ini dilakukan untuk mencatat perilaku siswa dalam kegiatan diskusi dalam kelas, atau mencatat perilaku siswa dalam mengikuti suatu proses pembelajaran. Observasi ini sangat penting dalam kegiatan pembelajaran fisika karena untuk menilai seberapa jauh minat dan motivasi intrinsik selama kegiatan pembelajaran berlangsung.

Agar observasi dapat berhasil dengan baik, maka diperlukan alat atau instrumen observasi. Instrumen observasi pada PTK merupakan pedoman bagi observer untuk mengamati hal-hal yang akan diamati. Dalam hal ini, observer menggunakan check list sebagai instrumen observasi.Check list atau daftar cek adalah pedoman observasi yang berisikan daftar dari semua aspek yang akan diobservasi sehingga observer tinggal memberi tanda ada atau tidak adanya dengan tanda cek $(\sqrt{ })$ tentang aspek yang diobservasi (Sanjaya, 2009: 54 ).

b. Metode Dokumentasi

Metode dokumentasi adalah metode pengumpulan data yang digunakan untuk menelusuri data historis (Bungin: 2001: 66). Adapun metode dokumen yang dimaksud dalam penelitian ini adalah buku-buku, catatancatatan, gambar dan transkrip nilai yang berhubungan langsung dengan penelitian dalam penelitian tindakan kelas ini yaitu tentang peningkatan hasil belajar siswa kelas $\mathrm{VIII}_{1}$ MTs Nurul Huda Sukaraja.

c. Tes/ulangan

Tes adalah instrumen pengumpulan data untuk mengukur kemampuan siswa dalam aspek kognitif, atau tingkat penguasaan materi pembelajaran (Sanjaya, 2009: 55). Jenis tes yang akan diterapkan dalam PTK ini adalah tes kelompok dan tes individual. Tes kelompok adalah tes yang dilakukan terhadap sejumlah siswa secara bersama-sama.Sedangkan tes individual adalah tes yang dilakukan kepada siswa secara perorangan.

\section{Teknik Analisis Data}

Menganalisis data adalah suatu proses mengolah dan menginterpretasi data dengan tujuan untuk mendudukkan berbagai informasi sesuai dengan fungsinya sehingga memiliki makna dan arti yang jelas sesuai dengan tujuan penelitian. Untuk menghitung persentase peningkatan hasil belajar siswa, maka menggunakan rumus teknik analisa persentase. Rumus yang digunakan adalah rumus persentase sebagai berikut:

$$
P=\frac{F}{N} \times 100 \%
$$

Setelah mendapat hasil berupa persentase kemudian hasilnya dapat ditafsirkan dengan kalimat kualitatif sebagai berikut:

Tabel 1. Persentase dan Kategori Penilaian

\begin{tabular}{cc}
\hline Persentase & Kategori \\
\hline $76 \%-100 \%$ & Kategori baik \\
$56 \%-75 \%$ & Kategori cukup \\
$40 \%-55 \%$ & Kategori sangat \\
$0 \%-35 \%$ & Kategori jelek \\
\hline
\end{tabular}


Untuk menghitung nilai rata-rata siswa, peneliti menggunakan Mean. Mean adalah nilai rata-rata dari data (berupa skor) yang diperoleh dari pengumpulan data dimana besarannya bersifat kuantitas dan tidak bervariasi (Soepeno, Bambang: 1997). Untuk menganalisa data mengenai rata-rata prestasi belajar siswa di kelas VIII $_{1}$ MTs Nurul Huda Sukaraja, penulis menggunakan teknik analisis data kuantitatif yaitu menggunakan rumus mean sebagai berikut:

$$
M=\frac{\sum x}{N}
$$

\section{Indikator Keberhasilan}

Sebagai tolok ukur keberhasilan penelitian tindakan kelas adalah:

a. Siswa mencapai tuntas belajar kognitif apabila siswa mampu menyelesaikan, menguasai kompetensi atau tujuan pembelajaran minimal $70 \%$ dari seluruh tujuan pembelajaran (sesuai dengan nilai KKM pada MTs Nurul Huda). Sedangkan keberhasilan kelas diperoleh dari jumlah siswa yang mampu menyelesaikan atau mencapai minimal $70 \%$ sekurangkurangnya $85 \%$ dari jumlah siswa yang mengikuti tes.

b. Dalam penelitian ini siswa dipandang mencapai tuntas belajar afektif apabila siswa mampu menguasai kompetensi minimal $70 \%$ dari tujuan pembelajaran, sedangkan keberhasilan kelas dicapai apabila dari jumlah siswa yang mencapai minimal $70 \%$ sekurang-kurangnya $75 \%$ dari jumlah siswa yang mengikuti tes.

c. Siswa dipandang mencapai tuntas belajar psikomotorik apabila siswa mampu menguasai kompetensi minimal $75 \%$ dari tujuan pembelajaran, sedangkan keberhasilan kelas dicapai apabila dari jumlah siswa yang mencapai minimal $75 \%$ sekurang-kurangnya $75 \%$ dari jumlah siswa yang mengikuti tes.

\section{HASIL PENELITIAN}

Pembelajaran Fisika pada materi optik di kelas VIII 1 MTs Nurul Huda ini dilakukan dalam dua siklus. Pada setiap siklus, data yang diambil adalah yang berhubungan dengan aktivitas belajar siswa selama proses pembelajaran dan nilai tes dari evalusi hasil belajar pada akhir siklus. Hasil belajar siswa dalam penelitian ini mencakup tiga ranah yaitu ranah kognitif, afektif, dan psikomotorik. Data hasil penelitian dari siklus ke siklus dapat dideskripsikan sebagai berikut:
Tabel 2.Ringkasan hasil belajar kognitif siswa kelas VIII 1 MTs Nurul Huda Sukaraja

\begin{tabular}{clccc}
\hline \multirow{2}{*}{ No } & Keterangan & $\begin{array}{c}\text { Sebelum } \\
\text { tindakan }\end{array}$ & \multicolumn{2}{c}{ Sesudah tindakan } \\
Siklus I & Siklus II \\
\hline $\mathbf{1}$ & Nilai tertinggi & 70 & 85 & 95 \\
$\mathbf{2}$ & $\begin{array}{l}\text { Nilai } \\
\text { terendah }\end{array}$ & 60 & 65 & 65 \\
$\mathbf{3}$ & $\begin{array}{l}\text { Nilai rata- } \\
\text { rata }\end{array}$ & 65.22 & 70.43 & 80.43 \\
$\mathbf{4}$ & $\begin{array}{l}\text { Ketuntasan } \\
(\%)\end{array}$ & 22 & 61 & 87 \\
\hline
\end{tabular}

Berdasarkan Tabel 2 dapat dilihat bahwa nilai rata-rata siswa kelas VIII 1 MTs Nurul Huda Sukaraja tahun pembelajaran 2015/2016 setelah diterapkan model pembelajaran Quantum Teaching pada siklus I mengalami peningkatan dan kembali meningkat pada siklus II. Perbandingan nilai-nilai hasil belajar pada ranah kognitif dalam penelitian ini dapat dilihat pada Gambar 2.

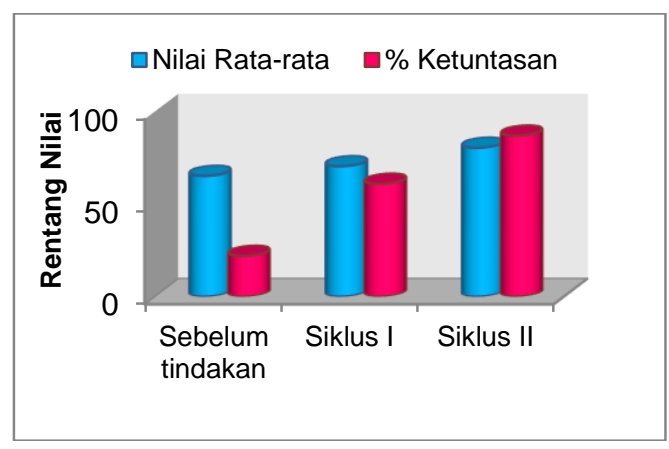

Gambar 2. Grafik hasil belajar kognitif siswa kelas VIII 1 MTs Nurul Huda Sukaraja

Tabel 3. Ringkasan hasil belajar ranah afektif siswa kelas VIII 1 MTs Nurul Huda Sukaraja

\begin{tabular}{clcccc}
\hline \multirow{2}{*}{ No } & Indikator & \multicolumn{2}{c}{ Minat } & \multicolumn{2}{c}{ Motivasi } \\
& Siklus I & Siklus II & Siklus I & Siklus II \\
\hline 1 & $\begin{array}{l}\text { Perhatian } \\
\text { (Attention) }\end{array}$ & $67 \%$ & $84 \%$ & $72 \%$ & $86 \%$ \\
2 & $\begin{array}{l}\text { Relevansi } \\
\text { (Relevance) }\end{array}$ & $68 \%$ & $83 \%$ & $70 \%$ & $87 \%$ \\
3 & $\begin{array}{l}\text { Percaya Diri } \\
\text { (Confidence) }\end{array}$ & $68 \%$ & $86 \%$ & $69 \%$ & $83 \%$ \\
4 & $\begin{array}{l}\text { Kepuasan } \\
\text { (Satisfaction) }\end{array}$ & $70 \%$ & $84 \%$ & $67 \%$ & $82 \%$ \\
\hline & Rata-rata & $\mathbf{6 8 \%}$ & $\mathbf{8 5 \%}$ & $\mathbf{7 0 \%}$ & $\mathbf{8 5 \%}$ \\
\hline
\end{tabular}

Berdasarkan Tabel 3 dapat dilihat bahwa nilai rata-rata afektif siswa kelas $\mathrm{VIII}_{1}$ MTs Nurul Huda Sukaraja tahun pembelajaran 2015/2016 untuk ketercapaian minat dan motivasi setelah diterapkan model pembelajaran quantum teaching mengalami peningkatan dari siklus I ke siklus II. Grafik perbandingan nilai afektif siswa setiap siklus dapat dilihat pada Gambar 3. 


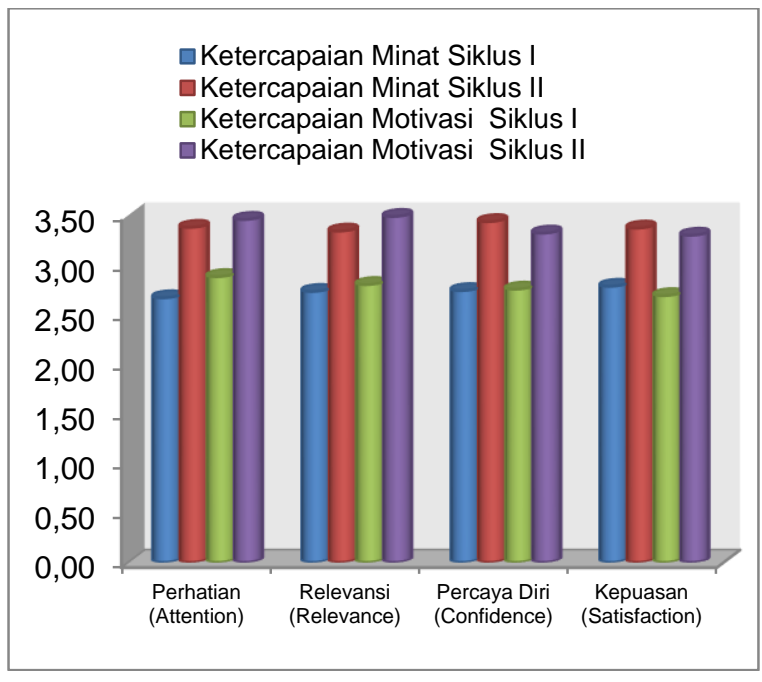

Gambar 3. Grafik hasil belajar afektif siswa kelas VIII 1 MTs Nurul Huda Sukaraja

Tabel 4. Ringkasan hasil belajar ranah psikomotorik siswa kelas VIII ${ }_{1}$ MTs Nurul Huda Sukaraja

\begin{tabular}{|c|c|c|c|}
\hline \multirow{2}{*}{ No } & \multirow{2}{*}{ Indikator ketercapaian } & \multicolumn{2}{|c|}{ Ketercapaian } \\
\hline & & Siklus I & Siklus II \\
\hline 1. & $\begin{array}{l}\text { Maju ke depan kelas dan } \\
\text { menunjukkan bagian mata } \\
\text { pada alat peraga mata } \\
\text { yang disediakan oleh guru }\end{array}$ & $71 \%$ & $85 \%$ \\
\hline 2. & $\begin{array}{l}\text { Menggunakan kamera } \\
\text { dengan baik dan benar }\end{array}$ & $71 \%$ & $82 \%$ \\
\hline 3. & $\begin{array}{l}\text { Menggunakan lup dengan } \\
\text { baik dan benar }\end{array}$ & $72 \%$ & $82 \%$ \\
\hline 4. & $\begin{array}{l}\text { Menggunakan mikroskop } \\
\text { dengan baik dan benar }\end{array}$ & $68 \%$ & $83 \%$ \\
\hline 5. & $\begin{array}{l}\text { Menggunakan alat-alat } \\
\text { optik dengan aman }\end{array}$ & $70 \%$ & $85 \%$ \\
\hline 6. & $\begin{array}{l}\text { Mahir menggambarkan } \\
\text { pembentukan bayangan } \\
\text { benda pada masing- } \\
\text { masing alat optik }\end{array}$ & $67 \%$ & $88 \%$ \\
\hline & Rata-rata & $70 \%$ & $84 \%$ \\
\hline
\end{tabular}

Berdasarkan Tabel 4 dapat dilihat bahwa persentase nilai rata-rata psikomotorik siswa kelas VIII 1 MTs Nurul Huda pada siklus I sebesar 70\%, sedangkan pada siklus II mengalami peningkatan sebesar $14 \%$ dengan pencapaian persentase nilai rata-rata sebesar $84 \%$. Grafik perbandingan persentase nilai rata-rata psikomotorik siswa setiap siklus dapat dilihat pada Gambar 4.

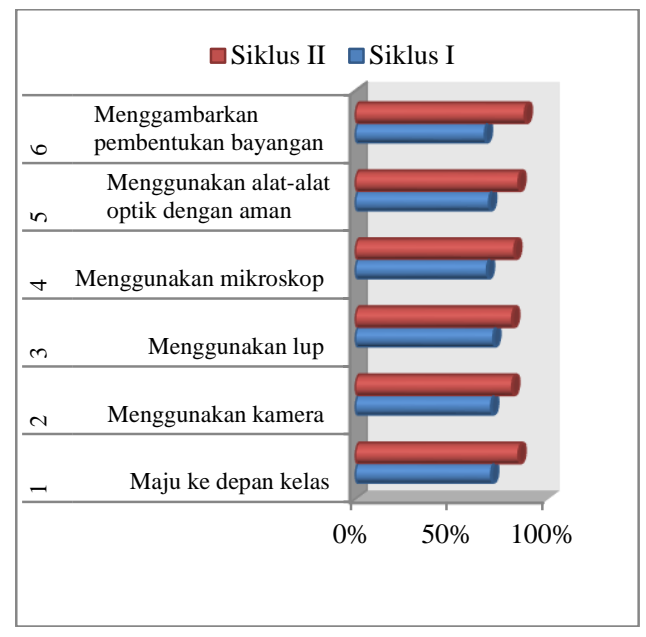

Gambar 4.Grafik hasil belajar psikomotorik siswa kelas VIII ${ }_{1}$ MTs Nurul Huda Sukaraja

\section{Siklus I}

\section{PEMBAHASAN}

Pembahasan siklus I diawali dengan refleksi dan mengidentifikasi masalah yang terjadi pada pembelajaran fisika yang telah dilakukan sebelumnya. Ringkasan hasil nilai ulangan fisika pada materi sebelumnya dapat dilihat pada tabel 2. Hasil analisis data nilai ulangan fisika pada materi sebelumnya mengindikasikan bahwa kegiatan pembelajaran belum maksimal dan berdampak pada rendahnya nilai hasil belajar siswa, padahal kegiatan pembelajaran sudah menggunakan metode inquiry terbimbing. Seyogyanya hal ini berdampak dengan meningkatnya nilai hasil belajar siswa, namun karena metode tersebut masih belum bisa memaksimalkan pemahaman siswa maka dicari solusi metode belajar lain yang lebih cocok digunakan bagi siswa kelas VIII ${ }_{1}$ MTs Nurul Huda. Maka dipilihlah metode quantum teaching.

a. Tahap Perencanaan

Untuk melaksanakan pembelajaran quantum teaching dan melihat apakah metode ini dapat meningkatkan prestasi dan nilai hasil belajar siswa, maka dalam tahap perencanaan dilakukan pembuatan rencana pelaksanaan pembelajaran (RPP) untuk tiga kali pertemuan (2x40 menit), lembar observasi untuk menilai psikomotorik siswa, angket untuk menilai minat dan motivasi siswa, dan alat evaluasi berupa soal pilihan ganda. Skenario pembelajaran serta alat dan bahan yang akan digunakan dalam pelaksanaan pembelajaran tertuang dalam draft RPP siklus I.

b. Tahap Pelaksanaan dan Penerapan

Tahap pelaksanaan dan penerapan metode quantum teaching memperlihatkan siswa banyak yang mengalami kesulitan dalam memahami materi yang disampaikan. 
Kesulitan-kesulitan tersebut disebabkan karena siswa kurang berani mengungkapkan permasalahan-permasalahan selama proses pembelajaran berlangsung, kurang termotivasi dan berminat dalam belajarnya, serta mengalami kesulitan dalam pemecahan contoh soal yang diberikan. Hasil belajar kognitif pada siklus I jika dibandingkan dengan nilai ulangan pada materi sebelumnya mengalami peningkatan yaitu dari nilai rata-rata 65,22 menjadi 70,43 . Peningkatan nilai rata-rata ini diikuti juga dengan peningkatan persentase ketuntasan secara klasikal yaitu dari $22 \%$ menjadi 61\%. Walaupun sudah terjadi peningkatan pada hasil belajar kognitif sebesar $39 \%$, tetapi belum mencapai indikator keberhasilan kognitif dimana siswa yang mendapat nilai diatas 70 (standar KKM) sebanyak $85 \%$ maka siklus I belum mencapai tuntas secara klasikal.

Berdasarkan analisis data hasil belajar siswa ranah afektif yang meliputi motivasi dan minat pada siklus I, diperoleh persentase rata-rata sebesar $68 \%$ untuk angket minat dan $70 \%$ untuk angket motivasi. Dari hasil tersebut, ketika dikonsultasikan pada Tabel 2.1 masih didapatkan minat dan motivasi belajar pada siklus I terkategori cukup untuk aspek perhatian (attention), relevansi (relevance), percaya diri (confidence) dan kepuasan (satisfaction) penerapan model pembelajaran quantum teaching selama proses pembelajaran berlangsung.

Penilaian psikomotorik terdapat 6 indikator yang harus dicapai siswa selama kegiatan pembelajaran berlangsung. Keenam indikator tersebut dapat dilihat pada Tabel4. Pada pelaksanaannya ada dua indikator yang belum mencapai kriteria ketuntasan, hanya mendapatkan persentase sejumlah $68 \%$ dan $67 \%$. Penilaian psikomotorik diperoleh hasil yang belum tuntas secara klasikal pada siklus I, nilai rata-rata persentase psikomotorik $70 \%$. Ketidaktuntasan psikomotorik dikarenakan siswa belum terbiasa menggunakan alat-alat optik dan menggambarkan bentuk bayangan benda pada masing-masing alat optik.

Berdasarkan kegiatan yang diadakan pada siklus Isiswa memperoleh pengalaman dengan memperhatikan penjelasan guru yang menggunakan media ajar berupa model mata manusia, gambar mata, kamera, lup, dan mikroskop. Hal ini merupakan pengalaman baru bagi siswa yang belum pernah mereka dapatkan sebelumnya. Siswa lalu diminta untuk mengeksplorasi kemampuannya sesuai dengan instruksi dari guru, setelah menemukan (discovery) pengetahuan baru, siswa bisa menamai hal tersebut untuk kemudian didemonstrasikan di depan teman-temannya.
Diskusi yang berlangsung diakhiri dengan refleksi dari guru dan kemudian guru menggali lagi dengan menanyakan pertanyaan yang berkaitan dengan materi yang sedang dipelajari.

c. Refleksi

Setelah siswa selesai melakukan percobaan diskusi dan pengamatan, dilakukan refleksi terhadap pelaksanaan pembelajaran quantum teaching pada siklus I. Dalam proses pembelajaran ranah afektif menentukan keberhasilan seseorang, sehingga keberhasilan belajar siswa pada ranah kognitif dan psikomotorik sangat ditentukan oleh kondisi afektif siswa. Hasil dalam penelitian ini menunjukkan bahwa siswa sudah memiliki minat dan sikap positif untuk belajar namun hasil yang dicapai siswa belum maksimal.

Secara keseluruhan hasil refleksi siklus I adalah kegiatan pembelajaran yang dilaksanakan sudah hampir dapat dikatakan sukses/berhasil namun terdapat kekurangankekurangan dalam pelaksanaan pembelajaran quantum teaching sehingga ketiga ranah hasil belajar belum dapat dicapai secara maksimal. Kekurangan-kekurangan tersebut adalah : (1) Waktu yang digunakan melebihi waktu yang direncanakan dalam rencana pembelajaran, (2) Tidak seluruh siswa terlibat aktifdalam diskusi (3) Banyak siswa terlena dalam suasana lingkungan belajar yang menyenangkan sehingga hanya banyak bermain (4) Siswa kekurangan literatur dalam pengerjaan diskusi kelompok (5) Siswa mengalami kesulitan dalam pemecahan contoh soal yang diberikan.

\section{Siklus II}

\section{a. Tahap Perencanaan}

Dari hasil analisis kekurangan kegiatanpembelajaran pada siklus I, yaitutidak tepatnya alokasi waktu kegiatan, siswa yang kurang aktif dalam diskusi, banyak siswa yang bermain-main, kurangnya literatur siswa dalam pengerjaan diskusi kelompok serta kurangnya pemahaman siswa dalam memecahkan contoh soal, diperlukan perbaikan-perbaikan dalam kegiatan pembelajaran pada siklus I. Perbaikan tersebut diantaranya dengan mempertegas eksistensi siswa sehingga waktu kegiatan tidak hanya dihabiskan dengan bermain-main tidak jelas, namun tetap dalam suasana gembira yang terorganisir. Juga dengan mengurangi dominasi guru dalam proses diskusi, dan memotivasi siswa untuk belajar lebih berani mengemukakan pendapat atau jawaban dari suatu pertanyaan. Selanjutnya motivasi juga diberikan oleh guru dengan menjelaskan bagaimana penilaian dilakukan sehingga diharapkan siswa lebih aktif karena penilaian dilakukan bukan dari tes kognitif saja melainkan dari pengamatan secara langsung selama 
siswa melakukan kegiatan pembelajaran. Serta dengan memberikan beberapa literatur penunjang lain yang dapat digunakan siswa sebagai bahan diskusinya.

b. Pelaksanaan dan pengamatan

Pada tahap pelaksanaan, siswa melakukan kegiatan dengan batasan waktu yang ditentukan oleh guru. Masih dengan menggunakan alokasi waktu dan rancangan skenario pembelajaransebelumnya, pada siklus II ini siswa lebih banyak diberi motivasi dan disadarkan untuk lebih fokus dan giat dalam belajar.

Analisis data kognitif siswa dari hasil ulangan pada siklus II dan pengamatan siswa kelas VIII ${ }_{1}$ didapat informasi bahwa pemahaman siswa terhadap materi optik sudah memenuhi target yang diharapkan dalam indikator keberhasilan. Dari hasil analisis data afektif padasiklus II diperoleh peningkatan nilai rata-rata minat siswa dari $68 \%$ menjadi $85 \%$, serta peningkatan nilai rata-rata motivasi siswa dari $70 \%$ menjadi $85 \%$. Peningkatan pada hasil belajar afektif siklus II juga didukung dan mendukung peningkatan hasil belajar kognitif dan psikomotorik. Analisis data psikomotorik siswa pada siklus Ilmeningkat dari $70 \%$ menjadi $84 \%$.

\section{c. Refleksi}

Peningkatan nilai rata-rata hasil belajar kognitif, afektif dan psikomotorik disebabkan karena pelaksanaan pembelajaran quantum teaching telah berjalanlebih baik dari siklus I. Proses siswa dalam memahami materi optik sudah terlihat baik setelah siswa diberi pengalaman langsung dengan media ajar alat peraga serta pengalaman pemecahan soalsoal. Ketiga hasil belajar ini sudah memenuhi indikator ketuntasan klasikal sehingga siklus II dapat dikatakan sudah mencapai ketuntasan klasikal. Peningkatan nilai rata-rata hasil belajar kognitif, afektif, dan psikomotorik disebabkan karena pelaksanaan pembelajaran quantum teaching telah berjalanlebih baik dari siklus I.

Dari kedua siklus yang telah dilaksanakan dapat diketahui bahwa pembelajaran quantum teaching dapat meningkatkan pemahaman siswa pada materi optik. Hal ini dikarenakan dalam quantum teaching memberikan pengalaman yang nyata dan aktif kepada siswa. Proses memperoleh pengetahuan dalam pembelajaran quantum teaching akan menyebabkan siswa akan lama teringat dalam memperoleh suatu konsep sedangkan produk yang dihasilkan adalah meningkatnya hasil belajar kognitif (pemahaman), afektif, dan psikomotorik.

\section{PENUTUP}

Berdasarkan hasil penelitian dapat disimpulkan bahwa pembelajaran quantum teaching dapat meningkatkan hasil belajar siswapada materi optik di kelas VIII ${ }_{1}$ MTs Nurul Huda. Hasil belajar pada penelitian ini adalah hasil belajar kognitif (pemahaman), afektif, dan psikomotorik. Peningkatan nilai rata-rata kognitif pada siklus I dari 70,43 menjadi 80,43. Ketuntasan klasikal mengalami peningkatan dari $61 \%$ menjadi $87 \%$. Nilai rata-rata afektif siswa dalam hal minat meningkat dari siklus I sebesar $68 \%$ menjadi $85 \%$ pada siklus II.Nilai rata-rata psikomotoriksiklus I sebesar $70 \%$ meningkat pada siklus II menjadi $84 \%$.

Perbaikan-perbaikan pada pembelajaran siklus II diantaranya dengan:

1. Mempertegas eksistensi siswa sehingga waktu kegiatan tidak hanya dihabiskan dengan bermain-main tidak jelas, namun tetap dalam suasana gembira yang terorganisir.

2. Mengurangi dominasi guru dalam proses diskusi

3. Memotivasi siswa untuk belajar lebih berani mengemukakan pendapat atau jawaban dari suatu pertanyaan.

4. Menjelaskan bagaimana penilaian dilakukan sehingga diharapkan siswa lebih aktif karena penilaian dilakukan bukan dari tes kognitif saja melainkan dari pengamatan secara langsung selama siswa melakukan kegiatan pembelajaran.

5. Memberikan beberapa literatur penunjang lain yang dapat digunakan siswa sebagai bahan diskusinya.

6. Perbaikan-perbaikan ini memberikan dampak terhadap peningkatan hasil belajar pada siklus II.

\section{UCAPAN TERIMAKASIH}

Pada kesempatan ini penulis menyampaikan rasa terima kasih kepada kepala sekolah MTs Nurul Huda dan guru mata pelajaran IPA Terpadu di Kelas VIII MTs Nurul Huda Sukaraja Kec. Buay Madang Kab. OKU Timur.

\section{DAFTAR PUSTAKA}

Dimyati \&Mudjiono. (1999). Belajar dan Pembelajaran. Jakarta: Rineka Cipta.

Fuchan, Arif. (1982). Pengantar Penelitian Dalam Pendidikan. Surabaya: Usaha Nasional.

Laili Farihah. (2005). Model Pembelajaran Tipe STAD Pada Konsep Perubahan Lingkungan Fisik dan Prosesnya Dalam 
Upaya Meningkatkan Hasil Belajar Sains Siswa Kelas IV SD Negeri Sekaran Semarang Tahun 2005/2006. Jurusan Fisika: UNNES.

Mudjijo. (1995). Tes Hasil Belajar. Jakarta: Bumi Aksara.

Mulyani, Sri. (2006). Upaya Meningkatkan Hasil Belajar Siswa dengan Quantum Teaching Pada Sub Poko Bahasan Kalor Siswa Kelas VIII Semester 1 SMP Negeri 2 Ungaran Tahun Ajaran 2005/2006. Skripsi Publikasi. Semarang: Fisika FMIPA UNNES.

Mulyasa, E. 2004. Kurikulum Berbasis Kompetensi, Konsep Karakteristik dan Implementasi. Bandung: Remaja Rosda Karya.

Oemar Hamalik. (2008). Proses Belajar Mengajar. Jakarta: Bumi Aksara.

Sanjaya, Wina. 2009. Penelitian Tindakan Kelas. Jakarta: Kencana Prenada Media Group.

Sardiman. (2003). Interaksi dan Motivasi Belajar Mengajar. Jakarta: Raja Grafindo Persada.

Soepeno, Bambang. (1997). Statistik Terapan; dalam Penelitian IImu-ilmu Sosial dan Pendidikan.Jakarta: Rineka Cipta.

Sugiyono. (2007). Metode Penelitian Pendidikan: Pendekatan Kuantitatif, Kualitatif, dan $R \& D$. Bandung: Alfabeta.

Supriyono, K. (2003). Strategi Pembelajaran Fisika. rev. Ed. Malang: JICA 